\title{
Metabolic Profiles in Closely Controlled Diabetic Pregnancies during the Third Trimester
}

\author{
J. Jervell, K. T. Stokke, N. Moe, H. N. Haugen, and J. Vidnes \\ Departments of Medicine, Clinical Chemistry, Obstetrics and Gynaecology, and Paediatrics, Rikshospitalet, Oslo, Norway
}

Summary. In 5 closely controlled pregnant diabetics (duration of pregnancy 237-266 days) and 5 pregnant non-diabetics (duration of pregnancy 210-278 days) 4-hourly blood samples were taken throughout a $24 \mathrm{~h}$ period and analyzed for blood glucose, lactate, pyruvate, 3-hydroxybutyrate and acetoacetate, plasma non-esterified fatty acids (NEFA), glucagon and cortisol. $24 \mathrm{~h}$ urine specimen was analyzed for total catecholamines and 4-hydroxy-3-methoxymandelic acid. There were few significant differences in concentrations of metabolites and hormones in the two groups at any time, although the variations about the mean was usually greater in the diabetics. Thus for blood glucose in diabetics, mean value was 4.4 mmol/l, coefficient of variation $43 \%$; in non-diabetics $4.1 \mathrm{mmol} / 1$ and $10 \%$ respectively. Mean plasma 3-hydroxybutyrate in diabetics was $0.47 \mathrm{mmol} / \mathrm{l}$, coefficient of variation $55 \%$; in non-diabetics 0.44 $\mathrm{mmol} / \mathrm{l}$ and $37 \%$ respectively. Plasma non-esterified fatty acid levels were significantly higher in the diabetics $(0.47 \mathrm{mmol} / 1)$ than in the non-diabetics $(0.26 \mathrm{mmol} / 1)$. Coefficients of variation were $46 \%$ and $33 \%$ respectively. Two conclusions can be drawn; first, when near normal mean values for blood glucose are achieved, other metabolite and hormone levels are also near normal; second, even when the available means for diabetic control, strict diet and insulin-mixtures twice daily, are used at their maximum, metabolism in diabetics is more unstable than in non-diabetics.

Key words: Diabetic pregnancy, metabolic profile, diabetes mellitus, insulin therapy, metabolic control, glucagon, cortisol, growth hormone, ketone bodies, blood glucose, blood lactate, blood pyruvate, plasma non-esterified fatty acids.
Insulin treatment of the diabetic represents a form of replacement therapy. Subcutanously injected insulin, however, is not a physiological substitute for insulin produced by the $\beta$-cells; its release into the circulation will be independent of the blood glucose concentration and the other metabolic, nervous and hormonal factors which regulate the normal release of insulin. Furthermore, insulin released from the subcutaneous tissues will reach the systemic circulation directly, bypassing the portal vein and liver. The balance between the effects of insulin on the liver and the peripheral tissues in insulin treated diabetics will therefore differ from that in normal individuals.

In diabetic pregnancy normalization of metabolism is probably of major importance for the outcome $[4,12]$. In most studies blood glucose normalization has been the goal, and only recently have other metabolites been studied $[5,6]$.

The present study was undertaken to evaluate to what extent normalization of metabolism is possible in intensely controlled, hospitalized, insulin-dependent, pregnant diabetics.

\section{Materials and Methods}

\section{Patients}

The diabetic subjects, all with long-standing juvenile diabetes, were taking part in a special regimen for pregnant diabetics [9]. On this regimen they were admitted to the ward in the 33rd week of pregnancy; delivery usually took place 1-3 weeks before term. The study was performed during this period. A standard diet of 3 main meals and two smaller meals was given. Blood glucose concentration was determined 4 times daily $(0800,1200,1600$, $2000 \mathrm{~h}$ ) and insulin was given twice daily, before breakfast at $0800 \mathrm{~h}$ and at $1730 \mathrm{~h}$ before the main evening meal, as a mixture of intermediate-acting (isophane) and soluble insulin, the dose being adjusted daily. During the hospital stay the patients were encouraged to exercise regularly. 
Table 1. Data on the diabetic subjects

\begin{tabular}{|c|c|c|c|c|c|c|c|}
\hline $\begin{array}{l}\text { Patient } \\
\text { number }\end{array}$ & $\begin{array}{l}\text { Age } \\
\text { (years) }\end{array}$ & Parity & $\begin{array}{l}\text { Duration of } \\
\text { diabetes } \\
\text { (years) }\end{array}$ & $\begin{array}{l}\text { Daily b } \\
\text { insulin } \\
\text { dose } \\
\text { (i. u.) }\end{array}$ & $\begin{array}{l}\text { Duration of } \\
\text { pregnancy } \\
\text { at sampling } \\
\text { (days) }\end{array}$ & $\begin{array}{l}\text { Duration of } \\
\text { pregnancy } \\
\text { at delivery } \\
\text { (days) }\end{array}$ & $\begin{array}{l}\text { Birth } \\
\text { weight } \\
\text { of baby } \\
\text { (g) }\end{array}$ \\
\hline 1 & 27 & 0 & 20 & $\begin{array}{l}24+8 \\
16+8\end{array}$ & 248 & 259 & 3210 \\
\hline 2 & 20 & 0 & 9 & $\begin{array}{l}40+20 \\
24+12\end{array}$ & 249 & 269 & 4300 \\
\hline 3 & 22 & 2 & 12 & $\begin{array}{l}44+24 \\
12+16\end{array}$ & 260 & 265 & 3250 \\
\hline 4 & 34 & 2 & 23 & $\begin{array}{l}32+16 \\
24+20\end{array}$ & 237 & 263 & 3140 \\
\hline 5 & 29 & 0 & 11 & $\begin{array}{r}16+4 \\
8+8\end{array}$ & 266 & 271 & 3520 \\
\hline
\end{tabular}

a Patient 1-4 had simple retinopathy only, patient 5 no signs of angiopathy

b Insulin was given twice daily. The dose of isophane insulin is written first, the dose of soluble insulin second

Table 2. Data on the non-diabetic subjects

\begin{tabular}{lllllll}
\hline $\begin{array}{l}\text { Patient } \\
\text { number }\end{array}$ & $\begin{array}{l}\text { Age } \\
\text { (years) }\end{array}$ & Parity & $\begin{array}{l}\text { Duration of } \\
\text { pregnancy at } \\
\text { sampling } \\
\text { (days) }\end{array}$ & $\begin{array}{l}\text { Duration of } \\
\text { pregnancy at } \\
\text { delivery } \\
\text { (days) }\end{array}$ & $\begin{array}{l}\text { Bixth weight } \\
\text { of baby } \\
\text { (g) }\end{array}$ & Reason for hospitalization \\
\hline 6 & 27 & 1 & 210 & 242 & 2030 & Moderate hypertension \\
7 & 27 & 1 & 215 & 275 & 3100 & Low total estrogen in urine \\
8 & 27 & 1 & 278 & 281 & 3850 & Transverse lie \\
9 & 29 & 1 & 271 & 281 & 3500 & Transverse lie, placenta praevia \\
10 & 22 & 0 & 215 & 240 & 2450 & Antepartum haemorrhage \\
\hline
\end{tabular}

Table 1 shows the age, parity, duration of diabetes, duration of the pregnancy at the time of the study, insulin dosage and further course of pregnancy in the 5 diabetic subjects. In Table 2 are shown the age, parity, reason for hospitalization, duration of pregnancy at the time of the study, and further course of pregnancy in the 5 control subjects. None of the subjects were taking any medication at the time of study. All gave informed consent to the study, and all later gave birth to healthy babies.

On the day of the study blood samples were taken through an indwelling venous cannula at 0800 (fasting), 1200, 1600, 2000, 2400,0400 and $0800 \mathrm{~h}$. The samples at 0800 and $1200 \mathrm{~h}$ were taken before breakfast and lunch, at $1600 \mathrm{~h}$ one hour after their mid-afternoon snack, at $2000 \mathrm{~h} 2^{1 / 2} \mathrm{~h}$ after their evening meal, and at $2400 \mathrm{~h} 3 \mathrm{~h}$ after their evening snack.

The non-diabetics had usual hospital meals, no snacks at 1500 and $2100 \mathrm{~h}$, and were not given any dietary instructions.

\section{Methods}

Glucose was determined by a glucose oxidase method adapted for Auto-analyzer. Blood samples for lactate and pyruvate determinations were immediately mixed with equal volumes of ice-cold perchloric acid $(1 \mathrm{~mol} / \mathrm{l})$, and samples were kept frozen $\left(-20^{\circ} \mathrm{C}\right)$ until analyzed. The concentrations of lactate and pyruvate were determined by the Biochemica Test Combination (Boehringer Mannheim $\mathrm{GmbH}$ ). Ketone bodies (3-hydroxybutyrate and acetoacetate) were determined on the perchloric acid extracts by an enzymatic method [17]. The plasma concentration of nonesterified fatty acids (NEFA) was determined by a titrimetric method [13]. Plasma cortisol was determined by radioimmunoassay (Diagnostic Products Corporation, Los Angeles). The concentration of 4 hydroxy - 3 methoxy mandelic acid (HMMA) and catecholamines in urine were determined by routine methods, HMMA by spectrophotometry after oxidation with periodate, catecholamines by fluorimetry after conversion to lutin derivatives. Plasma glucagon was determined by radioimmunoassay [8, 14]. NOVO Research Institute kindly supplied the pancreas specific antiserum (K 964), glucagon for standards and $\left({ }^{125} \mathrm{I}\right)$ glucagon. All samples were assayed in triplicate. Unspecific glucagon activity was determined after treatment with charcoal (Norit A) to remove true glucagon, and subtracted from total glucagon to give true glucagon. Coefficient of variation of the assay was $9.4 \%$ at glucagon concentration of $60 \mathrm{ng} / \mathrm{l}$. The lower detection limit was approximately $20 \mathrm{ng} / \mathrm{l}$.

Student's t-test has been used to test for statistical significance, using $\mathrm{p}<0.05$ as the level of statistical significance.

\section{Results}

The results are given in Table 3 and 4. Blood glucose values did not differ significantly at any time, although the variations were greater in the diabetics, 
Table 3. Concentration of various metabolites in blood in pregnant diabetic (D) and non-diabetic subjects (N)

\begin{tabular}{|c|c|c|c|c|c|c|c|c|}
\hline Time & & 0800 & 1200 & 1600 & 2000 & 2400 & 0400 & 0800 \\
\hline $\begin{array}{l}\text { Glucose } \\
\mathrm{mmol} / \mathrm{l}\end{array}$ & D & $\begin{array}{c}4.6 \pm 1.7 \\
(2.7-6.2) \\
3.4 \pm 0.3 \\
(2.9-3.7)\end{array}$ & $\begin{array}{c}3.9 \pm 1.2 \\
(2.0-5.1) \\
4.4 \pm 0.5 \\
(4.0-5.2)\end{array}$ & $\begin{array}{c}4.1 \pm 0.9 \\
(3-5) \\
4.5 \pm 0.6 \\
(4.0-5.2)\end{array}$ & $\begin{array}{c}5.0 \pm 1.8 \\
(2.6-7.0) \\
4.6 \pm 0.3 \\
(4.1-5.0)\end{array}$ & $\begin{array}{c}3.8 \pm 2.2 \\
(1.8-7.4) \\
4.5 \pm 0.5 \\
(4.0-5.3)\end{array}$ & $\begin{array}{c}4.1 \pm 2.4 \\
(2.4-7.4) \\
3.7 \pm 0.3 \\
(3.3-4.0)\end{array}$ & $\begin{array}{c}5.3 \pm 3.2 \\
(2.5-10.4) \\
3.4 \pm 0.3 \\
(3.1-3.6)\end{array}$ \\
\hline $\begin{array}{l}\text { Lactate } \\
\mathrm{mmol} / \mathrm{l}\end{array}$ & $\mathrm{N}$ & $\begin{array}{c}0.9 \pm 0.3 \\
(0.6-1.3) \\
0.9 \pm 0.1 \\
(0.7-1.1)\end{array}$ & $\begin{array}{c}1.0 \pm 0.2 \\
(0.7-1.2) \\
0.9 \pm 0.3 \\
(0.6-1.3)\end{array}$ & $\begin{array}{c}0.9 \pm 0.2 \\
(0.7-1.2) \\
1.1 \pm 0.3 \\
(0.7-1.6)\end{array}$ & $\begin{array}{c}1.1 \pm 0.3 \\
(0.6-1.4) \\
1.1 \pm 0.4 \\
(0.8-1.5)\end{array}$ & $\begin{array}{c}0.9 \pm 0.3 \\
(0.6-1.3) \\
0.9 \pm 0.2 \\
(0.7-1.1)\end{array}$ & $\begin{array}{c}0.9 \pm 0.2 \\
(0.7-1.1) \\
1.1 \pm 0.3 \\
(0.6-1.3)\end{array}$ & $\begin{array}{c}0.9 \pm 0.2 \\
(0.7-1.3) \\
0.9 \pm 0.4 \\
(0.5-1.2)\end{array}$ \\
\hline $\begin{array}{l}\text { Pyruvate } \\
\mathrm{mmol} / 1\end{array}$ & $\mathrm{D}$ & $\begin{array}{c}0.06 \pm 0.02 \\
(0.04-0.08) \\
0.07 \pm 0.01 \\
(0.06-0.08)\end{array}$ & $\begin{array}{c}0.07 \pm 0.01 \\
(0.05-0.08) \\
0.09 \pm 0.04 \\
(0.05-0.14)\end{array}$ & $\begin{array}{c}0.07 \pm 0.01 \\
(0.05-0.09) \\
0.09 \pm 0.03 \\
(0.07-0.14)\end{array}$ & $\begin{array}{c}0.08 \pm 0.03 \\
(0.05-0.11) \\
0.09 \pm 0.03 \\
(0.05-0.13)\end{array}$ & $\begin{array}{c}0.07 \pm 0.02 \\
(0.05-0.1) \\
0.08 \pm 0.02 \\
(0.04-0.1)\end{array}$ & $\begin{array}{c}0.07 \pm 0.01 \\
(0.07-0.08) \\
0.1 \pm 0.03 \\
(0.05-0.12)\end{array}$ & $\begin{array}{c}0.07 \pm 0.01 \\
(0.06-0.09) \\
0.07 \pm 0.01 \\
(0.05-0.08)\end{array}$ \\
\hline $\begin{array}{l}\text { Lactate/ } \\
\text { Pyruvate } \\
\text { ratio }\end{array}$ & $\mathrm{D}$ & $\begin{array}{c}14.8 \pm 1.7 \\
(12.9-16.7) \\
12.8 \pm 0.8 \\
(11.6-13.8)\end{array}$ & $\begin{array}{c}14.2 \pm 2 \\
(11.7-15.7) \\
10.5 \pm 1.6 \\
(7.9-12)\end{array}$ & $\begin{array}{c}13.6 \pm 2.4 \\
(10-16) \\
11.4 \pm 0.9 \\
(10-12.2)\end{array}$ & $\begin{array}{c}13.0 \pm 2.3 \\
(10-16) \\
12.0 \pm 2.5 \\
(10-16)\end{array}$ & $\begin{array}{c}12.7 \pm 0.5 \\
(12-13.3) \\
12.2 \pm 3.2 \\
(8.8-17.5)\end{array}$ & $\begin{array}{c}11.9 \pm 1.8 \\
(10-13.8) \\
10.9 \pm 0.07 \\
(10-12)\end{array}$ & $\begin{array}{c}12.5 \pm 2.4 \\
(10-16.3) \\
12.2 \pm 4.5 \\
(8.3-17.1)\end{array}$ \\
\hline $\begin{array}{l}\text { NEFA } \\
\mathrm{mmol} / 1\end{array}$ & $\mathrm{D}$ & $\begin{array}{l}0.77 \\
(0.18-1.38) \\
0.42 \\
(0.28-0.73)\end{array}$ & $\begin{array}{l}0.36 \\
(0.22-0.51) \\
0.22 \\
(0.13-0.32)\end{array}$ & $\begin{array}{l}0.43 \\
(0.21-0.72) \\
0.24 \\
(0.19-0.41)\end{array}$ & $\begin{array}{l}0.40 \\
(0.17-0.57) \\
0.18 \\
(0.10-0.23)\end{array}$ & $\begin{array}{l}0.29 \\
0.09-0.40 \\
0.27 \\
(0.21-0.34)\end{array}$ & $\begin{array}{l}0.38 \\
(0.16-0.58) \\
0.24 \\
(0.13-0.30)\end{array}$ & $\begin{array}{l}0.67 \\
(0.25-1.05) \\
0.22 \\
(0.19-0.28)\end{array}$ \\
\hline $\begin{array}{l}\text { 3-Hydroxy- } \\
\text { buturate } \\
\text { mmol/1 }\end{array}$ & $\mathrm{N}$ & $\begin{array}{l}0.81 \\
(0.42-1.47) \\
0.49 \\
(0.31-0.62)\end{array}$ & $\begin{array}{l}0.31 \\
(0.24-0.48) \\
0.46 \\
(0.38-0.65)\end{array}$ & $\begin{array}{l}0.46 \\
(0.22-0.78) \\
0.38 \\
(0.28-0.59)\end{array}$ & $\begin{array}{l}0.39 \\
(0.22-0.61) \\
0.44 \\
(0.20-0.61)\end{array}$ & $\begin{array}{l}0.37 \\
(0.12-0.78) \\
0.47 \\
(0.18-0.73)\end{array}$ & $\begin{array}{l}0.39 \\
(0.16-0.61) \\
0.44 \\
(0.26-0.63)\end{array}$ & $\begin{array}{l}0.53 \\
(0.31-0.96) \\
0.39 \\
(0.16-0.49)\end{array}$ \\
\hline $\begin{array}{l}\text { Aceto- } \\
\text { acetate } \\
\mathrm{mmol} / \mathrm{l}\end{array}$ & $\mathrm{D}$ & $\begin{array}{l}0.26 \\
(0.12-0.39) \\
0.18 \\
(0.09-0.26)\end{array}$ & $\begin{array}{l}0.11 \\
(0.06-0.16) \\
0.16 \\
(0.08-0.24)\end{array}$ & $\begin{array}{l}0.13 \\
(0.06-0.17) \\
0.09 \\
(0.06-0.15)\end{array}$ & $\begin{array}{l}0.16 \\
(0.06-0.20) \\
0.13 \\
(0.09-0.17)\end{array}$ & $\begin{array}{l}0.10 \\
(0.06-0.25) \\
0.11 \\
(0.06-0.19)\end{array}$ & $\begin{array}{l}0.10 \\
(0.07-0.15) \\
0.14 \\
(0.08-0.19)\end{array}$ & $\begin{array}{l}0.17 \\
(0.09-0.29) \\
0.16 \\
(0.08-0.28)\end{array}$ \\
\hline
\end{tabular}

Values are given as mean $\pm \mathrm{SD}$, range in parenthesis

the coefficient of variation being $43 \%$ versus $10 \%$ in the non-diabetics. Figure 1 shows the individual curves for the two groups. Mean blood glucose through the whole period was $4.4 \mathrm{mmol} / \mathrm{l}$ for the diabetics, 4.1 in the non-diabetics.

Plasma NEFA were on the whole higher in the diabetic group, the difference did not, except at $2000 \mathrm{~h}$, reach statistical significance. Again the coefficient of variation was higher for the diabetics, $46 \%$ versus $33 \%$. Figure 2 shows the individual curves for the two groups. The mean NEFA for the $24 \mathrm{~h}$ was $0.47 \mathrm{mmol} / \mathrm{l}$ for the diabetics, $0.26 \mathrm{mmol} / 1$ for the non-diabetics; this difference is significant $(\mathrm{p}<$ 0.0005 ).

Three of the non-diabetic patients had relatively short duration of pregnancy (210-215 days) at the time of testing, and two had a long duration ( 271 and 278 days). As shown in figure 1 and 2 this did not seem to influence their blood glucose and NEFA levels.
Ketone body levels (3-hydroxybutyrate and acetoacetate) were remarkably similar in the two groups, again the coefficient of variation was greater in the diabetics, $55 \%$ versus $43 \%$ in the non-diabetics.

Blood lactate and pyruvate levels and their variation were similar in the two groups. The lactate/pyruvate ratios tended to be higher in the diabetics than in the non-diabetics, mean values for the whole period 13.2 and 11.7 respectively; the difference is statistically significant $(\mathrm{p}<0.005)$.

Plasma glucagon levels and variation did not differ significantly in the two groups. Plasma cortisol also tended to be higher in the diabetics; the differences are not significant.

Urinary excretion of catecholamines and HMMA did not differ in the two groups. Total urine catecholamines was $379 \mathrm{nmol} / 24 \mathrm{~h}$ and $306 \mathrm{nmol} /$ $24 \mathrm{~h}$ in diabetics and non-diabetics respectively; urinary HMMA $14 \mu \mathrm{mol} / 24 \mathrm{~h}$ and $18 \mu \mathrm{mol} / 24 \mathrm{~h}$, respectively. 

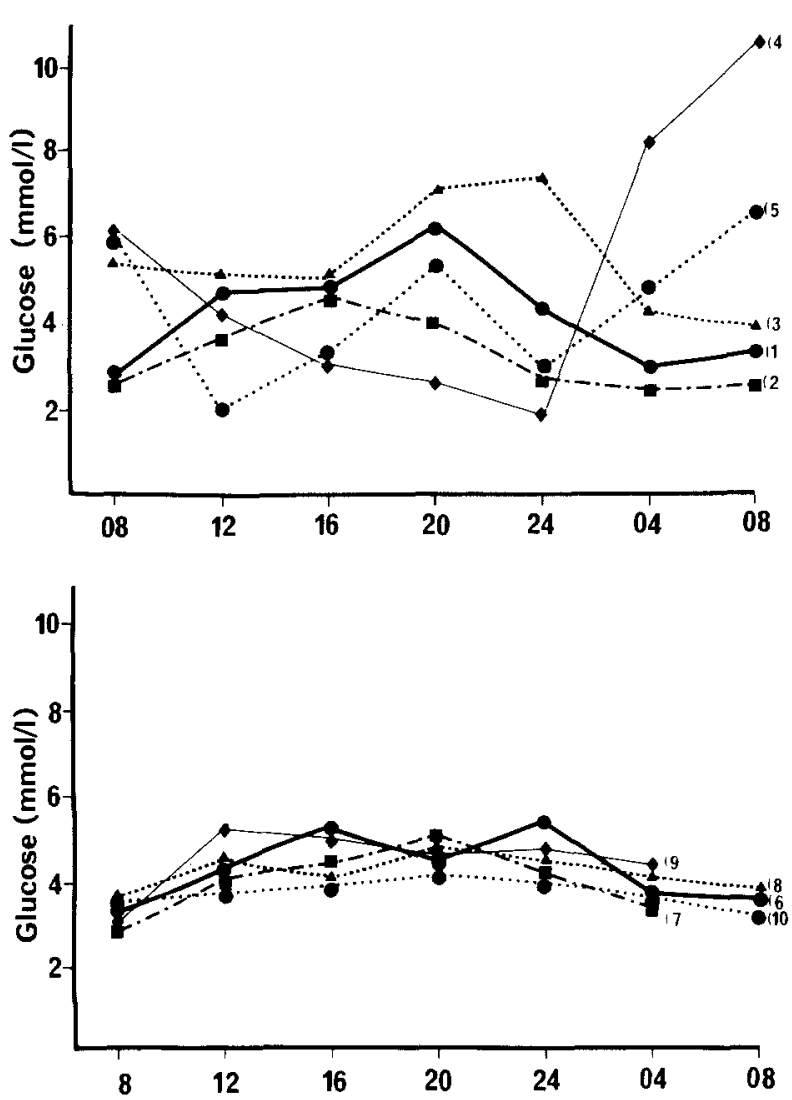

Fig. 1. Individual blood glucose values. Upper panel: diabetics; lower panel: non-diabetics. The curves are numbered for each patient as in Tables 1 and 2
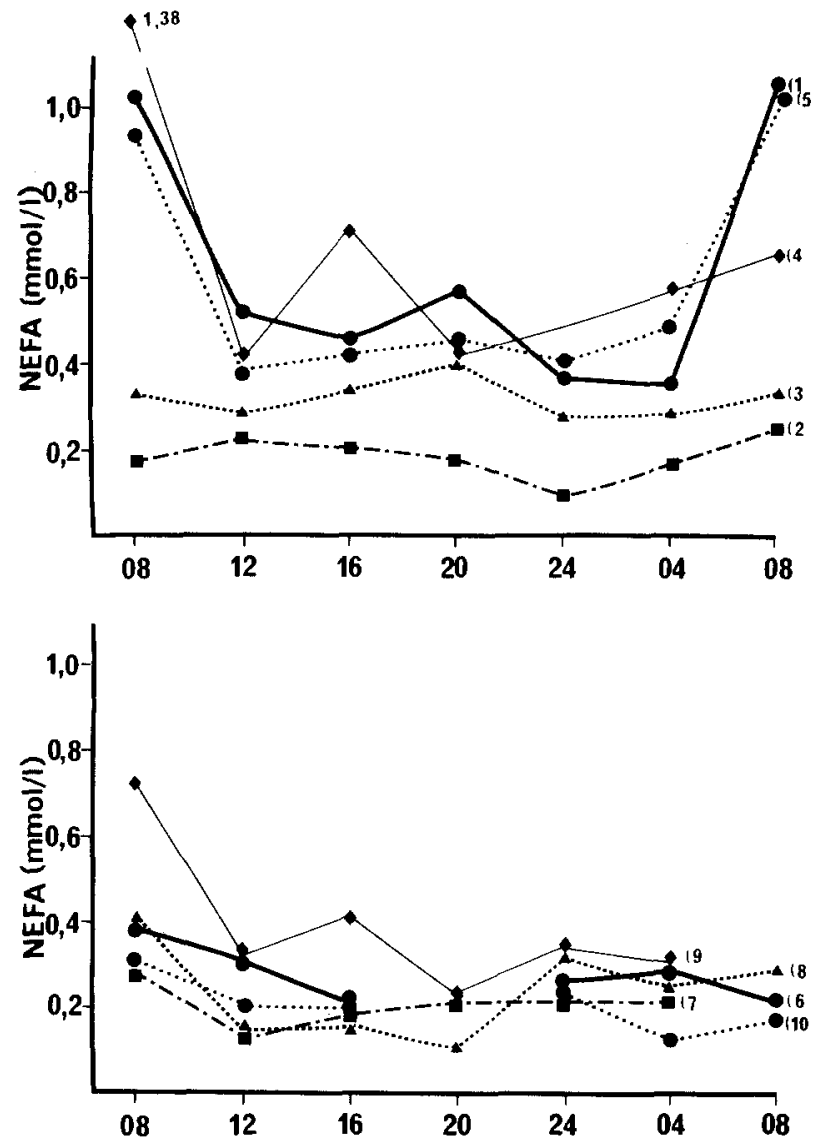

Fig. 2. Individual plasma NEFA values. Upper panel: diabetics, lower panel: non-diabetics. The curves are numbered for each patient as in Tables 1 and 2. At $2000 \mathrm{~h}$ the mean NEFA level in the diabetics is significantly higher than for the non-diabetics, $(\mathrm{p}<0.05)$

Table 4. Plasma glucagon and cortisol in pregnant diabetic (D) and non-diabetic (N) subjects

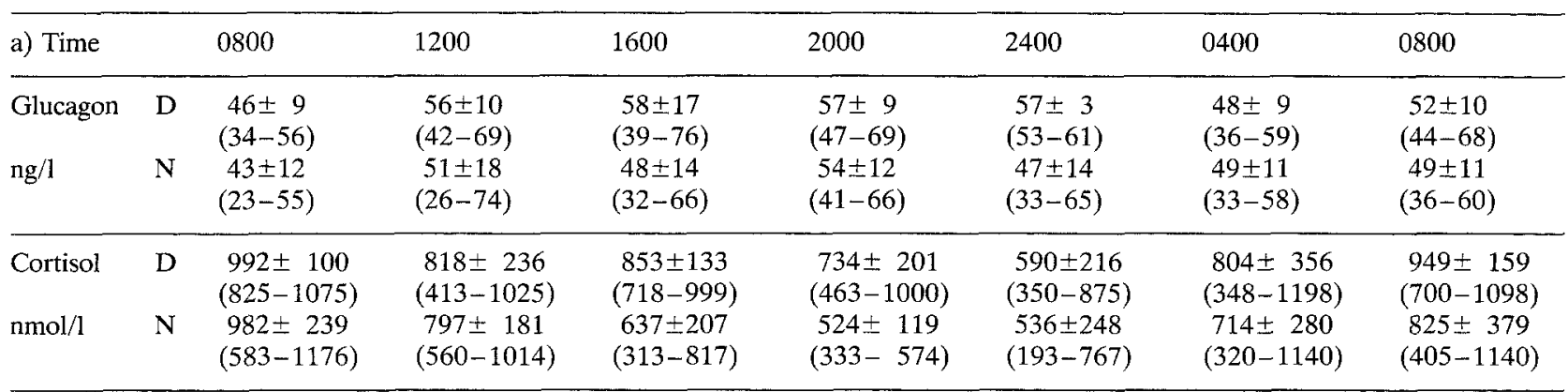

Results are given as mean $\pm \mathrm{SD}$, range in parenthesis. No differences at any time point between the two groups are significant ( $\mathrm{p}>0.05$ )

\section{Discussion}

The present study gives an indication of what can be obtained under optimal conditions by our presently available means in the treatment of diabetics in pregnancy. In practical terms the results are satisfactory, as the program has reduced the perinatal mortality significantly, to $3 \%(5 / 170)$ in those followed from before the 28th week of pregnancy [9]. This figure has to be compared to the total perinatal mortality in Norway which in 1976 was $1.32 \%$.

The study, like Buckle et al.'s [3] demonstrates that normalization of blood glucose, which has been the parameter for adjusting insulin dose, diet and 
general management also gives fairly normal blood levels for other metabolites and hormones. Nonesterified fatty acids are the exception; this may be of particular importance as it has been suggested that increased NEFA levels may explain adiposity in infants of diabetic mothers [11]. None of the 5 infants born to the diabetic mothers in the present study, however, were overweight.

There is a greater variation in the blood levels of many metabolites in the diabetic group, illustrating that their metabolism is more unstable than in nondiabetics, and that completlely physiological conditions cannot be obtained with subcutanously injected insulin.

Better stabilization in diabetic pregnancies can, however, probably be achieved by a glucose controlled insulin infusion system. At present this can only be used for short periods such as during labour [10].

It must be noted that the non-diabetic controls in this study are not normal controls; they were all hospitalized for various complications of pregnancy. Also they differed from the diabetics in duration of pregnancy. The influence of these factors is difficult to evaluate, but it is probable that if the non-diabetics had been completely normal and of the same duration of pregnancy, the variations in their blood metabolite levels might have been even smaller.

Our blood samples were drawn at 4 - hourly intervals. Others $[1,2,5,6,7,15,16]$ have demonstrated fluctuations which will not have been detected using our sampling schedule. Typical is the postprandial morning blood glucose, and postinsulin injection lactate rise found in insulin treated diabetics $[1,2]$. Quite low blood sugars were reached in some of the diabetic subjects, the lowest values being 1.8 $\mathrm{mmol} / \mathrm{l}$. It is possible that some even lower values occurred during the sampling intervals. It is, however, our general experience that severe symptomatic hypoglycemia is relatively rare in pregnant diabetics on this program [9].

Alberti et al. [1, 2] have recently published studies showing poor metabolic control, sometimes with very abnormal metabolic rhythms, in insulin dependent diabetics under more ordinary circumstances where no special effort to optimalize the control was used. The regimen used for pregnant diabetics may be a model for improving metabolic control in diabetics in general.

\section{References}

1. Alberti, K. G. M. M., Dornhorst, A., Rowe, A. S.: Metabolic rhythms in normal and diabetic man. Isr. J. Med. Sci. 11, 571-580 (1975)
2. Alberti, K. G. M. M., Nattrass, M.: Metabolic abnormalities in juvenile diabetics. In: Diabetes og diabetes behandling, II. Aagenæs, Ø. (Ed.), p. 125-137. Oslo: Nordisk Symposium 1976

3. Buckle, A. L. J., Nattrass, M., Cluett, B. E., Stubbs, W. A., Walton, R. J., Alberti, K. G. M. M., Clemens, A. H.: Blood metabolite concentrations in diabetics, effect of normalization of blood glucose using a glucose controlled insulin infusion system. Diabetologia 13, 385 (1977)

4. Karlson, K., Kjellmer, I.: The outcome of diabetic pregnancies in relation to mother's blood sugar level. Am. J. Obstet. Gynecol. 112, 213-220 (1972)

5. Gillmer, M. D. G., Beard, R.W., Brooke, F. M., Oakley, N. W.: Carbohydrate Metabolism in Pregnancy, Part I - Diurnal plasma glucose profile in normal and diabetic woman. $\mathrm{Br}$. Med. J. 1973 II, 399-402

6. Gillmer, M.D.G., Beard, R.W., Oakley, N.W., Brooke, F. M., Elphick, M. C., Hull, D.: Diurnal plasma free fatty acid profiles in normal and diabetic pregnancies. Br. Med. J. 1977 II, 670-673

7. Hansen, Aa. P., Johansen, K.: Diurnal patterns of blood glucose, serum free fatty acids, insulin, glucagon and growth hormone in normals and juvenile diabetics. Diabetologia 6, 27-33 (1970)

8. Heding, L. G.: Radioimmunological determination of pancreatic and gut glucagon in plasma. Diabetologia 7, 10-13 (1971)

9. Jervell, J., Moe, N., Skjæraasen, J., Blystad, W., Egge, K.: Diabetes mellitus and pregnancy. Management and results at Rikshospitalet, Oslo 1970-77. Diabetologia 16, 151-155 (1979)

10. Nattrass, M., Alberti, K. G. M. M., Dennis, K. J., Gillibrand, P. N., Letchworth, A. T., Buckle, A. L. J.: A glucose-controlled insulin infusion system for diabetic women during labour. Br. Med. J. 1978 II, 599-601

11. Szabo, A. J., Szabo, O.: Placental free fatty acid transfer and fetal adiposetissue development: an explanation of fetal adiposity in infants of diabetic mothers. Lancet 1974 II, 498-499

12. Pedersen, J.: The pregnant diabetic and her newborn. Copenhagen: Munksgaard 1977

13. Trout, D. L.: Titration of free fatty acids: a study of current methods and a new modification. J. Lipid Res. 1, 199-206 (1960)

14. Vidnes, J., Øyasæther, S.: Glucagon deficiency causing severe neonatal hypoglycemia in a patient with normal insulin secretion. Pediatr. Res. 11, 943-949 (1977)

15. Wildenhoff, K. E.: Diurnal variations in the concentrations of blood acetoacetate, 3-hydroxy butyrate and glucose in normal persons. Acta Med. Scand. 191, 303-306 (1972)

16. Wildenhoff, K. E.: The influence of diabetic regulation on the diurnal variation in blood and the urinary excretion of ketone bodies. Studies in newly diagnosed diabetics. Acta Med. Scand. 198, 127-133 (1973)

17. Williamson, D. H., Mellanby, J., Krebs, H. A.: Enzymic determination of $\mathrm{D}(-)-\beta$-hydroxybutyric acid and acetoacetic acid in blood. Biochem. J. 82, 90-96 (1962)

Received: July 20, 1978, and in revised form: November 7, 1978

Dr. J, Jervell

Rikshospitalet

Department of Medicine

Oslo I

Norway 